changed, whereas hexosamine values were gradually increased and seemed to be correlated to total cell count, but not to the count of adhered cells on the glass wall.

On the other hand, hexosamine and sialic acid contents of both the cells adhering to the glass wall were determined after washing with saline solution. The results are given in Table $I$. No remarkable difference in hexosamine and sialic acid contents was found between the cells.

The results show that no sialic acid-containing substance is accumulated in the media during the growth of tumor cells. This fact may give some support to the opinion that the increased sialic acid content of serum in tumor-bearing animals, as well as in patients, is not due to a production of sialoproteins in the tumor. In our laboratory it was also found that the cells of the C3H ascitic hepatomas do not show a higher level of hexosamine or sialic acid than the levels of normal liver cells of $\mathrm{C} 3 \mathrm{H}$ mice [5]. As to the origin of an increased serum level of sialic acid in tumor-bearing animals further experiments are necessary.

This work was supported in part by a grant for the scientific research from the Ministry of Education, which is gratefully acknowledged.

\title{
REFERENCES
}

1. Boas, N. F., J. Biol. Chem. 204, 553 (1953).

2. Böнm, P., Dauber, S. and BAumesieter, L., Klin. Wochschr. 32, 289 (1954).

3. Faillard, H. and Stickl, H., Hoppe-Seyler's Z. Physiol. Chem. 319, 220 (1960).

4. Kent, H. N. and Gey, G. O., Science 131, 666 (1960).

5. Kimura, A., Nagai, Y. and Turumi, K. To be reported.

6. Svennerholm, L., Acla Chem. Scand. 12, 547 (1958).

\section{A METHOD FOR MEASURING ACID MUCOPOLYSACCHARIDES IN SERUM-CONTAINING TISSUE CULTURE MEDIA ${ }^{1}$}

\author{
R. K. PRINCE and C. W. CASTOR ${ }^{2}$ \\ Rackham Arthritis Research Unit ${ }^{3}$ and Department of Internal Medicine, ${ }^{4}$ \\ University of Michigan Medical School, Ann Arbor, Michigan, U.S.A.
}

Received November 10, 1960

Although satisfactory chemical methods are available for the quantitative measurement of purified acid mucopolysaccharides, the accurate measurement of small amounts of these substances in protein-rich mixtures has been more difficult. Our

\footnotetext{
1 This study was carried out with the aid of U.S.P.H.S. Grant A3665.

2 Senior Investigator, Arthritis and Rheumatism Foundation.

3 The Rackham Arthritis Research Unit is supported by a grant from the Horace H. Rackham School of Graduate Studies.

4 Requests for reprints should be addressed to C. W. Castor, Rackham Arthritis Research Unit, Kresge Medical Research Bldg., Ann Arbor, Michigan.
} 
interest in this latter situation arose in the course of extended investigations of hyaluronic acid synthesis by human synovial connective tissue cells, in vitro, where fullest exploitation of the experimental system requires frequent, reliable measurements from many cultures $[3,4]$. A typical sample for analysis consists of $5-10 \mathrm{ml}$ of culture medium containing 1-20 $\mu \mathrm{g}$ of hyaluronic acid per $\mathrm{ml}$ and serum protein concentrations varying between 4000 and $16,000 \mu \mathrm{g} / \mathrm{ml}$ of culture medium.

A helpful step towards solving this problem was made by Badin, who observed that acid mucopolysaccharides co-precipitate with the euglobulin fraction under appropriate dialysis conditions [1]. To the concentration and deproteinization effected by precipitating the mucopolysaccharide with euglobulin, Bollet added perchloric acid deproteinization and protamine sulfate concentration steps [2]. The latter method requires four to five days to execute, involves two dialysis steps, and recovers 70 to 85 per cent of added hyaluronate when performed on culture medium containing 20 per cent serum. Alternatively, deproteinization of the euglobulin-mucopolysaccharide complex may be accomplished by sequential pepsin-trypsin digestion, with similar accuracy and expenditure of time [4]. The method described in this report possesses the advantage of simplicity and speed without significant sacrifice of sensitivity or accuracy.

\section{Material and methods}

Preparation of euglobulin precipitate.-Ten milliliter samples of tissue culture medium containing from 5-20 per cent human serum are placed in dialysis bags and equilibrated against $1 / 150 M$ citrate-phosphate buffer, $\mathrm{pH} 5.8$. The dialysis is carried out at $4^{\circ} \mathrm{C}$ against at least 50 volumes of buffer with one change of the buffer midway during the procedure. If the buffer is agitated with a magnetic stirrer, the dialysis may be terminated in $18 \mathrm{hr}$; in the absence of agitation, a satisfactory precipitate is obtained in $48 \mathrm{hr}$.

Recovery and suspension of euglobulin precipitate.--The contents of each dialysis bag is transferred quantitatively to centrifuge tubes. It has been our practice to wash the bag three times with buffer, adding the washings to the centrifuge tube. Centrifugation is carried out at $12,000 \mathrm{rpm}$ for ten minutes, the supernantant solution discarded and the tubes allowed to drain. Three millilitres of $2.0 \mathrm{M}$ acetate buffer, $\mathrm{pH}$ 7.0 , are next added to each tube and the precipitate stirred with warming. The sample is allowed to stand at room temperature for one hour, at which time it is usually distinctly opalescent.

Protein precipitation.-The samples are then placed in a boiling water bath for three minutes to precipitate the bulk of the residual protein. After the tubes have cooled, the precipitate is loosened from the vessel wall by shaking and then packed down by centrifugation for 20 minutes at $12,000 \mathrm{rpm}$. The supernatant solution is decanted, and saved for analysis. One milliliter aliquots of the supernatant solution may be used for determination of uronic acid content by the carbazole method [5]. Since a majority of the acid mucopolysaccharides contain an equimolar amount of uronic acid, one can calculate the amount of a particular mucopolysaccharide present, assuming that one knows on other grounds which mucopolysaccharide is present, and that a mixture is not present. Lacking information concerning the identity or number of mucopolysaccharides in the sample, the results should be expressed in terms of micromoles of "uronic acid-containing acid mucopolysaccharide". 
Mucopolysaccharide recovery data were based on uronic acid determinations carried out on portions of the same solutions of acid mucopolysaccharide that were added to the serum-containing culture medium. The protein-free hyaluronic acid was prepared by electrodeposition [8], and was of sufficiently high molecular weight to give appreciable viscosity in 0.1 per cent aqueous solution. Two preparations of sodium chondroitin sulfate from bovine tracheal cartilage were used in the recovery studies, one

TABLE I. Recovery of varying amounts of hyaluronic acid added to $10 \mathrm{ml}$ cullure medium containing 20 per cent serum.

\begin{tabular}{cclr}
\hline $\begin{array}{c}\text { Hyaluronic acid } \\
\text { added }(\mu \mathrm{g} / 10 \mathrm{ml})\end{array}$ & $\begin{array}{c}\text { No. of } \\
\text { samples }\end{array}$ & \multicolumn{2}{c}{$\begin{array}{c}\text { Hyaluronic acid recovered (\%) } \\
\text { Range }\end{array}$} \\
\hline & 2 & $98.6-103.1$ & Mean \\
\hline 50 & 4 & $79.7-95.5$ & 100.8 \\
75 & 2 & $75.6-83.8$ & 89.8 \\
100 & 14 & $76.8-99.7$ & 79.7 \\
150 & 5 & $78.1-91.5$ & 86.7 \\
200 & 4 & $83.0-92.8$ & 84.7 \\
Total & 31 & $75.6-103.1$ & 87.8 \\
\hline
\end{tabular}

TABLE II. Recovery of hyaluronic acid in presence of varying amounts of serum.

\begin{tabular}{cc}
\hline $\begin{array}{c}\text { Concentration of } \\
\text { serum in medium } \\
\%\end{array}$ & $\begin{array}{c}\text { Hyaluronic acid } \\
\text { recovered } \\
\%\end{array}$ \\
\hline & \\
5 & 81.5 \\
10 & 83.6 \\
20 & 82.7 \\
40 & 72.7 \\
60 & 78.6 \\
\hline
\end{tabular}

crude and the second a protein-free preparation which has been carefully characterized $[6,7]$, having an average molecular weight of 16,300. The heparin used was a commercially available sodium salt (Heparin Sodium, Testagar and Co., Detroit, Michigan).

Results

Since hyaluronidase lability studies and viscosimetric measurements suggested that hyaluronic acid was the only mucopolysaccharide present in significant quantity in culture medium removed from human synovial connective tissue cell cultures, it was used for the majority of the recovery studies to test the method described 
above. Ten milliliter samples of medium were prepared, containing $2.0 \mathrm{ml}$ (20 per cent) human serum, Eagle's synthetic medium, and varying amounts of protein-free hyaluronic acid prepared by electrodeposition. The optical density change observed in medium blanks, due to traces of mucopolysaccharide in the serum component, was always small (0.01-0.03 O.D. units). This blank value is subtracted from the samples prior to calculating recovery of added hyaluronate. Table I summarizes recovery studies with hyaluronic acid in medium containing 20 per cent serum.

\section{TABLE III. Recovery of chondroitin sulfuric acid and heparin from} medium containing 20 per cent serum.

\begin{tabular}{|c|c|c|}
\hline \multicolumn{3}{|c|}{ Mucopolysaccharide added, $\mu \mathrm{g} / 10 \mathrm{ml}$} \\
\hline Chondritin sulfate & Heparin & Recovery (\%) \\
\hline 100 & & 85 \\
\hline 100 & & 83 \\
\hline 125 & & 71 \\
\hline 125 & & 70 \\
\hline 125 (crude) & & 75 \\
\hline 125 (crude) & & 78 \\
\hline & 100 & 69 \\
\hline & 100 & 70 \\
\hline & 150 & 62 \\
\hline & 150 & 67 \\
\hline
\end{tabular}

To test the effect of increased protein concentration in the initial sample on ultimate recovery of hyaluronate, $100 \mu \mathrm{g}$ of hyaluronic acid was added to media in the presence of varying concentration of serum. Table II illustrates the observed recoveries. The samples with 40 and 60 per cent serum developed brown color on heating with sulfuric acid during the carbazole procedure, clean color being limited to those samples which initially had 20 per cent human serum or less.

Whether hyaluronic acid is formed in vivo as a mucopolysaccharide-protein complex remains controversial, and there is no evidence at present suggesting the formation of such a complex by cultured cells. However, to test the capacity of the present method to measure hyaluronate in its "native" state, pooled normal human joint fluid was diluted and analyzed. As standards, one milliliter aliquots were dialyzed, treated exhaustively with testicular hyaluronidase, and deproteinized by heating to $100^{\circ} \mathrm{C}$ in 10 per cent trichloroacetic acid. Uronic acid was then measured in the supernatant solution by the carbazole method. The uronic acid content of the normal joint fluid was also determined following pepsin-trypsin digestion. A concentration of $2.5 \mathrm{mg}$ hyaluronic acid per ml of initial joint fluid was found, the two methods agreeing within five per cent. The mean recovery of "native" hyaluronic acid by the method outlined in this report was 81.4 per cent over eight trials where dilutions of joint fluid were included in medium samples. 
In order to test the usefulness of the method for measuring other uronic acidcontaining mucopolysaccharides, chondroitin sulfuric acid and heparin were added to culture medium containing 20 per cent human serum. Table III illustrates the recoveries which were obtained.

In the recovery data presented in the tables, duplicate carbazole determinations on the final deproteinized sample agreed within five per cent. Protein in the final sample was $0.2 \mathrm{mg} / \mathrm{ml}$ or less, while hexose (measured by the anthrone method) varied between 5 and $9 \mu \mathrm{g} / \mathrm{ml}$, a level that gave no spurious color in the carbazole procedure.

\section{Discussion}

The method outlined in this report provides a relatively rapid, simple, and reproducible means of measuring the concentration of acid mucopolysaccharides in tissue culture medium where conventional amounts of serum are included as a medium component. This procedure can be completed in two or three days and dispenses with one dialysis step as well as the critical perchloric acid protein-precipitation step in the Bollet technique. In our hands, particularly for the measurement of hyaluronic acid, the procedure described here has provided more consistent recovery data than either of the other methods listed. When applied to medium samples from synovial cultures, the heat precipitation method described in this report yielded values in close agreement with those obtained by the Bollet procedure.

A point worthy of emphasis concerns the $\mathrm{pH}$ of the acetate buffer used to dissolve the euglobulin-mucopolysaccharide complex. This buffer must be at $\mathrm{pH} 7.0$, otherwise protein is inadequately removed during the heating step and is available to contribute interfering color during the carbazole procedure. Media containing only non-human serum (horse, fetal calf) may yield inferior recovery of acid mucopolysaccharides. This difficulty can be avoided by adding 10 per cent human serum to the samples and blank before carrying out the procedure described in this report.

\section{Summary}

The details of a simple, relatively rapid method for measuring uronic acid-containing acid mucopolysaccharides in protein-rich tissue culture media are presented. The procedure would appear to be most useful in those situations where hyaluronic acid and chondroitin sulfate are the primary mucopolysaccharides present.

\section{REFERENCES}

1. Badin, J. and SGhubert, M., J. Clin. Invest. 34, 1312 (1955).

2. Bollet, A. J., Seraydarian, M. W. and Simpson, W. F., J. Clin. Invest. 36, $1328,1957$.

3. Castor, C. W., Arth. and Rheum. 2, 259 (1959).

4. Castror, C. W. and Fries, F. F., J. Lab. Clin. Med. 57, 394 (1961).

5. Dische, Z., J. Biol. Chem. 167, 189 (1947).

6. Mathews, M. B. and Dorfman, A., Arch. Biochem. 42, 41 (1953).

7. Mathews, M. B., Roseman, S. and Dorfman, A., J. Biol. Chem. 188, 327 (1951).

8. Roseman, S., Watson, D. R., Duff, I. F. and Robinson, W. D., Federation Proc. 14, 878 A (1955). 